\title{
Study and Characterization of Pump Control System Tools in Mini Open Channel Water Flow Simulator
}

\author{
Bernadus Herdi Sirenden ${ }^{1 *}$, Aditia Warman ${ }^{2}$ and Eka Oktavianus Partogi \\ Napitupulu ${ }^{3}$ \\ ${ }^{1}$ Physics Research Center - Indonesian Institute of Sciences (LIPI), PUSPIPTEK Region, South \\ Tangerang 15314, Indonesia \\ ${ }^{2,3}$ Department of Physics, Faculty of Mathematics and Natural Science, Universitas Sumatera Utara, \\ Medan 20155, Indonesia
}

\begin{abstract}
This study aims to study the characterization of the pump control system in a mini open channel water flow simulator. This pump control system aims to facilitate operators in controlling pumps based on the Internet of Thing (IoT). The sample in this study focuses on red objects, where the sample can be monitored through a recording device that has been provided, and can be made in the form of realtime graphics. The results showed that in the simulator trial, the pump control system and the recording device were in the good category. After repairs are made, the development results are in the very good category, because they produce accurate results on the pump control system. Thus, the pump control system can be used and developed for large-scale canal water flow.
\end{abstract}

Keyword: control system, simulator, Internet of Thing (IoT).

Received 01 July 2020 | Revised [15 July 2020] | Accepted [27 August 2020]

\section{Introduction}

A river is a large and elongated flow of water that flows continuously from the upstream as a source to the downstream as the estuary. Rivers located underground are referred to as "underground rivers", for example, underground rivers in Hang Soon Dong Caves in Vietnam, underground rivers in Yucatan (Mexico), underground rivers in Pindul Caves (Indonesia). In the case study, a river simply enters the ground before finding another body of water. The cycle of rainwater that falls on land then flows into the sea or large water reservoirs such as rivers and lakes. One part of the hydrological cycle starts from a spring that flows into a river. Water in rivers is generally collected from precipitation, such as rain, dew, springs, underground runoff, and melted ice / snow in subtropical countries. The speed of water flow in rivers or in this study the term canal will be used, which is one of the factors that can be used by the Meteorology, Climatology and Geophysics Agency (BMKG) in predicting flood natural disasters [1-3].

\footnotetext{
*Corresponding author at: Physics Research Center - Indonesian Institute of Sciences (LIPI), PUSPIPTEK Region, South Tangerang 15314, Indonesia
}

E-mail address: bernadus.herdi.sirenden@lipi.go.id 
From the case study above, in this research, pump and motor components will be used to adjust the speed of water flow. The purpose of the motor is to move the pump so that the water can move. The motor is pre-programmed to provide automatic and constant speed. The motor speed is regulated using PWM (Pulse Width Modulation) [4-6].

\section{Methods}

The design and manufacture of solutions in this study based on the focus of the research were carried out with the prototype development method can be seen in Figure 1. This pump control system uses the ESP-32 microcontroller as a supporting application for the IoT concept, as a controller, processor, and data sender [7-8].

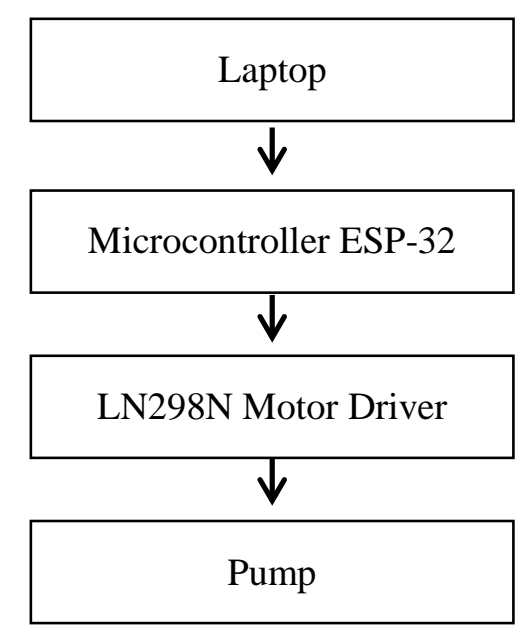

Figure 1. Block Diagram

The structural design of a motor control system and monitoring of an object is built from the ESP-32 as a microcontroller. Figure 1 shows that the media file system consists of several block diagrams, namely: Laptop, ESP-32 Microcontroller, LN298N Motor Driver, and pump.

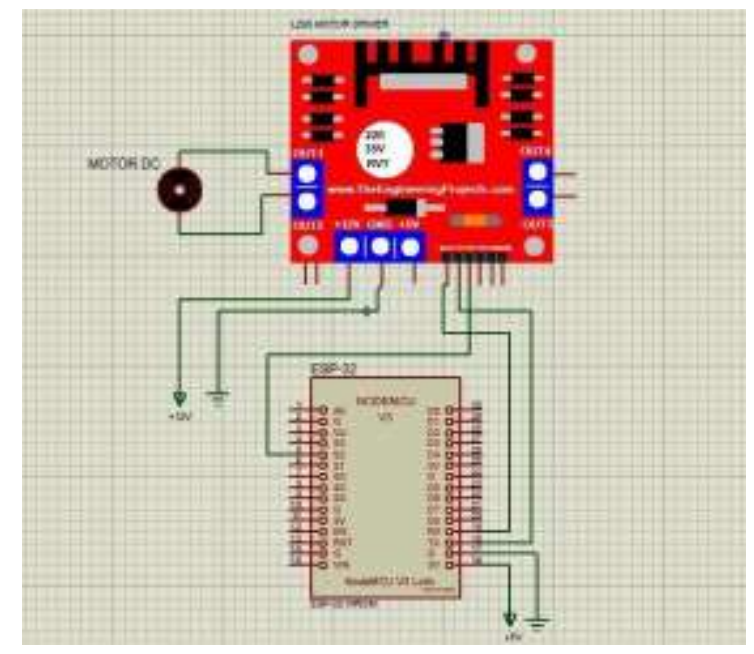

Figure 2. Overall circuit 


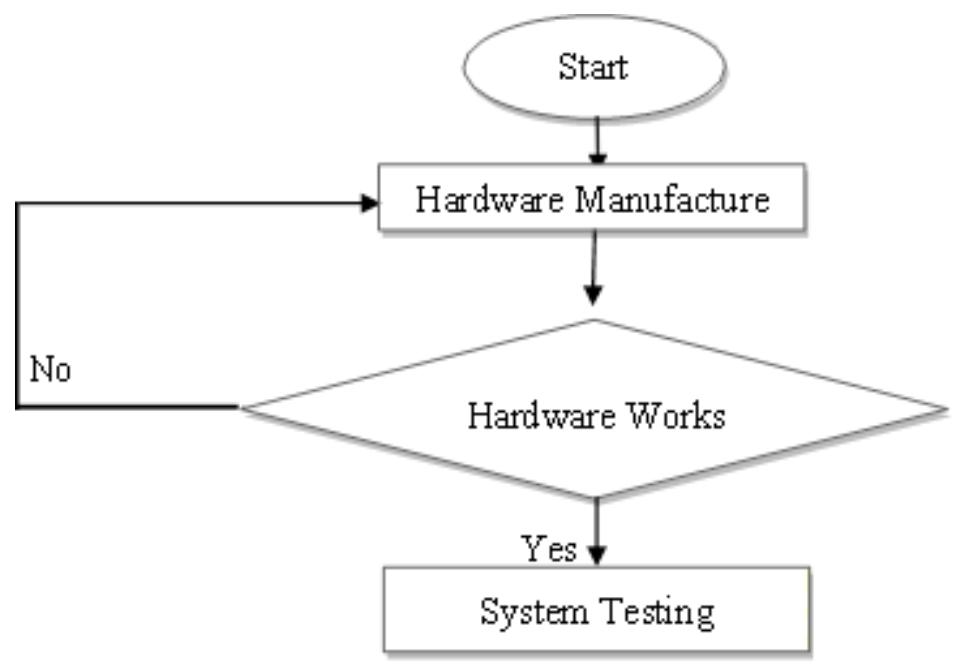

(a)

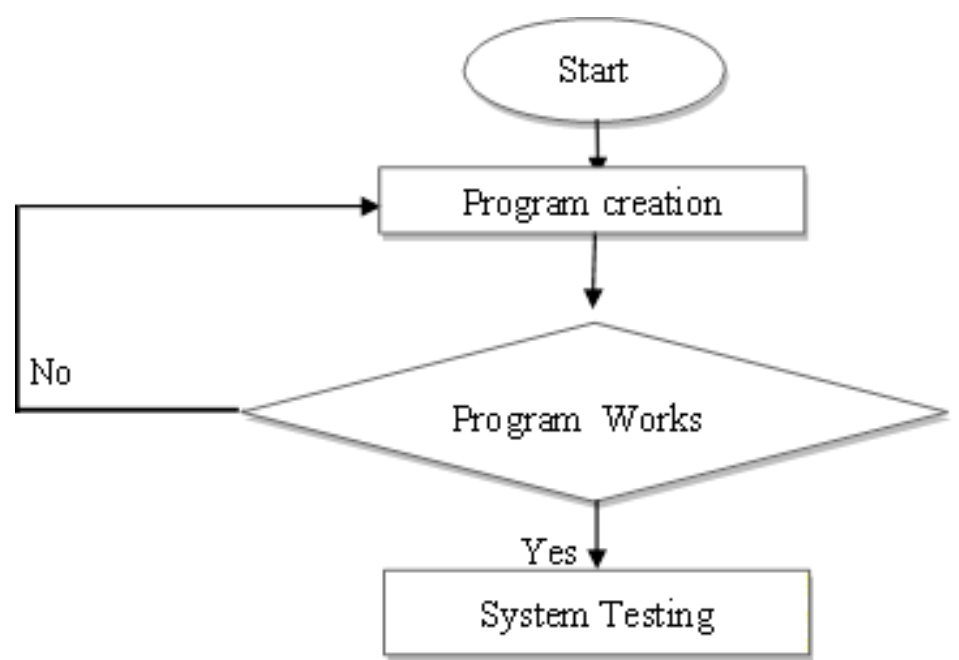

(b)

Figure 3. Flowchart of Hardware and Software Manufacturing

Figure 3 is a flowchart or the flow chart above is a flow of work processes for programs that work on ESP-32. Figure 3 shows that the process starts from initialization and initial value. The results of the initialization on the microcontroller are in the form of an IP address, then the IP address is retrieved in the browser so that it can be used to control wireless-based pumps.

\section{Result and Discussion}

PWM pulse testing is carried out using Proteus software. High pulse width transmission over a period of a square signal in the form of a periodic voltage is supplied to the motor as a power source. If the greater the ratio of the high signal duration to the signal period, the faster the motor rotates [9-10]. 


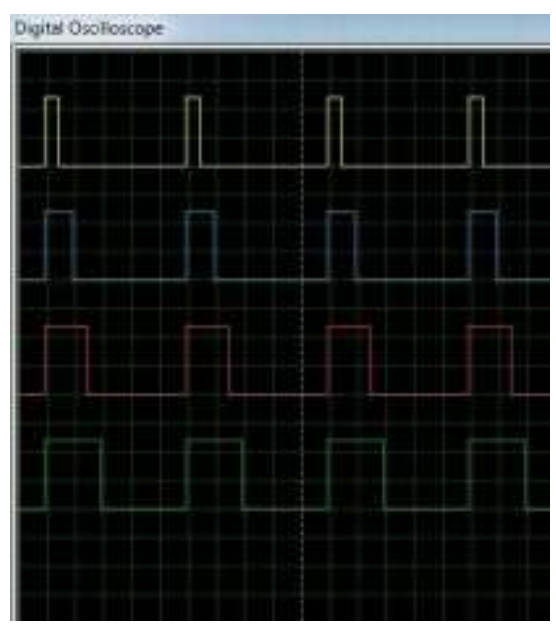

Figure 4. PWM Duty Cycle Pulse

Testing the output voltage on the microcontroller is carried out to determine the characteristics of the changes in the microcontroller output with the motor to the changes in the duty cycle. This measurement is carried out when the source voltage (adapter) is 12 volts. Based on the data on changes in duty cycle and voltage output in Table 1, the characteristics of the output voltage increase with the larger the duty cycle.

Table 1. Measurement results for voltage sensor input and output

\begin{tabular}{cc}
\hline $\begin{array}{c}\text { Duty Cycle } \\
(\%)\end{array}$ & $\begin{array}{c}\text { Voltage } \\
\text { (Volt) }\end{array}$ \\
\hline 20 & 3.53 \\
30 & 4.57 \\
40 & 5.63 \\
50 & 6.71 \\
60 & 7.69 \\
70 & 8.68 \\
80 & 9.70 \\
90 & 10.66 \\
100 & 11.65 \\
\hline
\end{tabular}

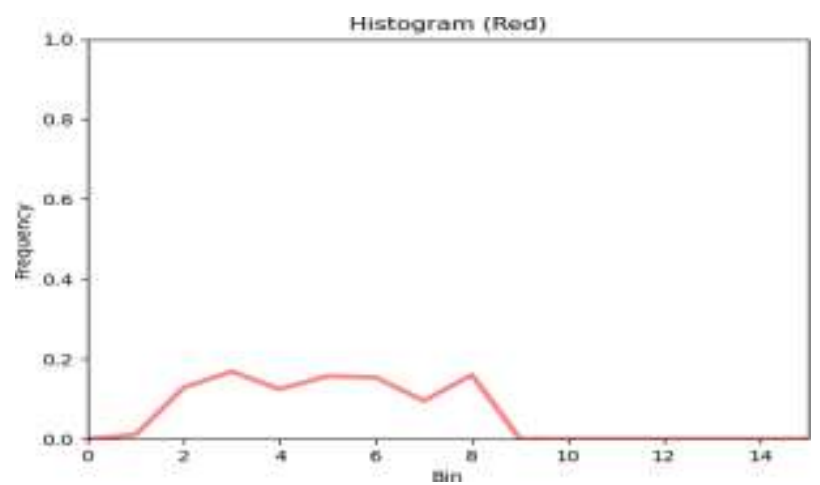

Figure 5. Duty Cycle 


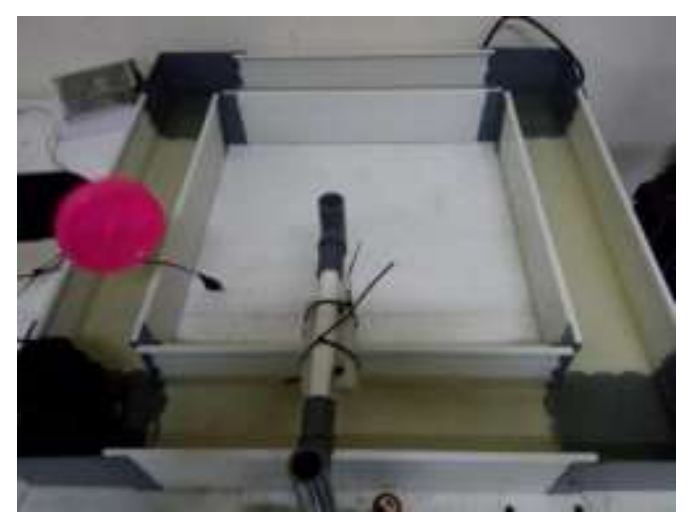

Figure 6. Shooting Video Using ESP-32

Figure 6 is a video taking using the ESP-32 microcontroller. The purpose of this video capture test is to measure the speed of water flow due to changes in pump speed. If the pump gets faster, the red object will move faster. The pump in this study serves to simulate the flow of canal water.

\section{Conclusion}

The prototype of a realtime pump control system using technology (IoT) has been successfully created by having passed the testing stages well. The results of the pump control system test data in the mini open channel water flow simulator produce the pulse values sent to the pump control accurately. This is because the pump control system prototype has met the standards and is good for use in canal water flow. In the monitoring of the pump control system, a red object is obtained as a sample that moves in the mini open channel water flow, the results are faster moving if the pulses sent are greater.

\section{REFERENCES}

[1] I. B. Pramono and P. B. Putra, "Tipologi Daerah Aliran Sungai untuk Mitigasi Bencana Banjir di Daerah Aliran Sungai Musi," Jurnal Penelitian Pengelolaan Daerah Aliran Sungai, vol. 1, no. 2, pp. 143-165, 2017..

[2] A. K. Neno, H. Harijanto and A. Wahid, "Hubungan Debit Air dan Tinggi Muka Air di Sungai Lambagu Kecamatan Tawaeli Kota Palu," WARTA RIMBA, vol. 4, no. 2, pp. 1-8, 2016.

[3] I. Sujono, Restorasi Air Sungai Brantas (Water Restoration of Brantas River), pp. 1-16, 2019,

[4] A. P. Malvino, Elektronika Komputer Digital: Pengantar Mikrokomputer, Jakarta: Erlangga, 1994.

[5] Ubaedilah, "Analisa Kebutuhan Jenis dan Spsifikasi Pompa untuk Suplai Air Bersih di Gedung Kantin Berlantai 3 PT Astra Daihatsu Motor," Jurnal Teknik Mesin, vol. 5, no. 3, pp. 119-127, 2016.

[6] A. S. S. Azhar and E. Aryanto, "Pengendalian Kecepatan Motor DC Pada Penyangrai Kopi Menggunakan PWM Berbasis ATMEGA 16," Gema Teknologi, vol. 19, no. 1, pp. 12-17, 2016.

[7] V. Pravalika, and C. R. Prasad, "Internet of Things Based Home monitoring and Device 

control using ESP 32", IJRTE, pp. 2277-3878.

[8] M. Babiuch, P. Foltýnek, and P. Smutný, "Using the ESP32 Microcontroller for Data Processing", In 2019 20th International Carpathian Control Conference (ICCC), IEEE, pp. 1-6, May 2019.

[9] K. M. Cho, W. S. Oh, Y. T. Kim, and H. J. Kim, "A new switching strategy for pulse width modulation (PWM) power converters", IEEE Transactions on Industrial Electronics, vol. 54, no. 1, pp.330-337, 2007.

[10] K. Yamanaka, E. Watanabe, T. Terada, Y. Tanaka, and Y. Terazono, Yaskawa Electric Corp,. Method for controlling PWM pulse. U.S. Patent 6,751,105, 2004. 